\title{
Characterization of Acute Hepatitis Virus A Genotype in Korea
}

\author{
Mi Hyun Kim', Hayana Choi', Kun Sik Pak², Chi Nam Seong ${ }^{2}$ and Hyun Wook Cho² \\ ${ }^{1}$ Department of Clinical Pathology, Hankook Hospital, Gwangiu 502-260, Korea \\ ${ }^{2}$ Department of Biology, College of Bio-Industry Science, Sunchon National University, Sunchon 540-742, Korea
}

Received November 1, 2012 /Revised January 18, 2013 / Accepted January 21, 2013

\begin{abstract}
In Korea, most hepatitis A virus is the IA genotype, but reports of other genotypes have increased recently. Therefore, the purpose of this study is to conduct a genotypic analysis of acute hepatitis A virus. From April 2010 to April 2011, clinical specimens from 20 patients hospitalized with acute hepatitis A and 36 sera positive for anti-HAV IgM were obtained, and the genotype of the VP1/P2A region was analyzed. RNA sequences of the VP1/P2A junction region were amplified using RT-PCR, and the sequences were compared. From 50 sequences amplified, 4 sequences $(8 \%)$ belonged to genotype IA. The remaining $46(92 \%)$ belonged to genotype IIIA. The results indicate that the genotype of the hepatitis A virus has changed from IA to IIIA in Korea.
\end{abstract}

Key words : Genotype, hepatitis A virus, VP1/P2A region

\section{서 론}

1980년대 전후 우리나라에서는 바이러스성 급성 간염의 경 우 B형 바이러스 감염이 주된 원인이었으나, 2001년 1월부터 2003년 12월 사이 서울소재 한 병원에서 조사 보고된 바에 의하면 $\mathrm{A}$ 형 바이러스 감염이 $49.5 \%$ 로 가장 많았고 이어서 B형 이 $45.2 \%, \mathrm{C}$ 형이 $3.8 \%, \mathrm{E}$ 형이 $1.6 \%$ 로 나타나 $\mathrm{A}$ 형의 비율이 증가하기 시작하였다고 하였다[24]. 이런 결과에서 볼 수 있는 것처럼 급성 간염의 흔한 원인으로 현재는 $\mathrm{A}$ 형 간염바이러스 (Hepatitis A virus, HAV)가 주목받고 있다. 국내에서는 이미 1996년도와 1997년도에 걸친 조사 보고에서도 20대의 경우 $\mathrm{A}$ 형 간염 항체 양성율이 $50 \%$ 이상으로 나타나 선진국형 간염 으로 이행되고 있다고 하였다[15]. 이런 A형 감염의 증가경향 은 한국 질병관리본부 인터넷상의 통계자료를 통해서도 확인 된다. 즉 2000년 지정전염병으로 추가되고 또 2001년부터 감 염조사 이후, A형 감염 환자가 2001년 105명에서 2006년 1,937 명으로 지속적으로 증가되었다고 보고되었다.

간염을 유발하는 $\mathrm{HAV}$ 는 Picornaviridae과(family)의 Hepatovirus 속(genus)으로 분류되며, HAV 유전체는 $7.5 \mathrm{~kb}$ 로 구성된 선형의 positive sense RNA 바이러스로 한 개의 large open reading frame을 가지고 있다[20]. 이것은 구조 단 백질을 지정하는 $\mathrm{P} 1$ 과, 비구조적 단백질을 지정하는 $\mathrm{P} 2, \mathrm{P} 3$ 라

\footnotetext{
*Corresponding author

Tel : +82-61-750-3614, Fax : +82-61-750-3608

E-mail : hwcho@sunchon.ac.kr

This is an Open-Access article distributed under the terms of the Creative Commons Attribution Non-Commercial License (http://creativecommons.org/licenses/by-nc/3.0) which permits unrestricted non-commercial use, distribution, and reproduction in any medium, provided the original work is properly cited.
}

는 총 3개의 기능적 부위로 나뉘고[18, 22, 28], 이 중 P1 부위는 다시 $\mathrm{VP} 1, \mathrm{VP} 2, \mathrm{VP} 3, \mathrm{VP} 4$ 지역으로 세분된다. 그리고 $\mathrm{P} 2, \mathrm{P} 3$ 부위는 바이러스 증식에 필요한 비구조적 단백질을 표현하는 것으로 알려져 있다[20]. 그리고 $\mathrm{HAV}$ 는 간세포에서 분비되는 담즙이나, $85^{\circ} \mathrm{C}$ 이하의 열, 산에 대해서 강한 저항성을 나타내 는 안정된 바이러스이다[1]. 따라서 $\mathrm{HAV}$ 유전체는 변이가 적 다. 특히 VP1과 VP2 연접 부위(VP1/P2)의 염기서열 차이를 통해 그 바이러스가 지역적으로 어디에서 기원하였는지를 밝 힐 수 있다[20]. 따라서 A형 간염 환자의 역학조사에서 $\mathrm{HAV}$ 의 염기서열의 차이 또는 변이 정도를 확인하는 것이 중요하 다고 할 수 있다 $[1,20]$. 보고에 의하면 $\mathrm{HAV}$ 의 유전체 중에서 유전자형이나 아유전자형을 구분할 때도 $\mathrm{VP} 1 / \mathrm{P} 2 \mathrm{~A}$ 부위의 염 기서열을 분석하는데, 유전자형의 경우 약 $15 \sim 20 \%$ 의 염기서 열 변이를 보이며, 아유전자형의 경우 $7.0 \sim 7.5 \%$ 염기서열 변 이를 보인다[18, 20]. 따라서 $\mathrm{VP} 1 / \mathrm{P} 2 \mathrm{~A}$ 부위의 염기서열을 분 석하는 것이 현재까지 가장 많이 이용되고 있으며 데이터도 많이 축적되어 있다.

사람의 $\mathrm{HAV}$ 혈청형은 한가지로 알려져 있는데[20], 이것은 다르게 표현하면 여러 종류의 $\mathrm{HAV}$ 유전자형에 대하여 단일 클론 항체가 만들어짐을 의미한다. 따라서 다른 RNA 바이러 스와는 다르게 이런 높은 $\mathrm{HAV}$ 의 항원 보존성 때문에 $\mathrm{HAV}$ 에 감염되거나 백신을 맞을 경우 장기간 면역성이 생기며 추후 다른 분리주의 $\mathrm{HAV}$ 재감염에 대하여도 보호를 받을 수 있다 $[20,21]$. 혈청형과는 달리 유전자형은 모두 일곱 가지로 이 중 사람에서 발견되는 유전자형은 I, II, III, VII 4가지이고 그 외 3 가지 $\mathrm{IV}, \mathrm{V}, \mathrm{VI}$ 은 원숭이 종류에서 분리된 것이다. 특 히, II형과 VII형이 초기에 분리 확인되었지만 추후 연구를 통 해 VII형은 II형에 속하는 또 다른 아유전자형으로 생각되고 있고, I형과 III형이 가장 광범위하게 사람을 감염시키는 유전 
자형으로 알려져 있다[18]. 국내에서도 A형 간염의 7개의 유전 자형 중에서 I 유전자형의 아형인 IA 유전자형이 2000년 초 까지 보고되었으며[10], 또한 2005년도 5월부터 7월 사이에 의 료 종사자들을 대상으로 한 감염조사에서 IA 유전자형이 주요 한 감염원인 이라고 하였다[19]. 그러나 2008년도 4월부터 8월 까지 조사한 바에 의하면 IIIA 유전자형이 더 주요한 감염 요 소라고 하였다[29].

따라서 본 연구에서는 최근 우리나라에서 유행하는 급성 $\mathrm{A}$ 형 간염으로 내원한 환자들의 혈청에서 $\mathrm{HAV}$ 유전자를 역전 사-중합효소연쇄반응(RT-PCR)으로 증폭하여 HAV 각 유전자 형에 대해서 알아보고자 하였다.

\section{재료 및 방법}

\section{대상군}

2010년 4월부터 2011년 4월까지 광주광역시에 위치한 K 종 합병원에 급성 $\mathrm{A}$ 형 간염으로 입원한 환자 20 명과 서울에 소재 한 임상검사 전문센터인 S센터에 anti-HAV IgM 검사가 의뢰 된 36개의 검체 등 총 56 명으로부터 얻은 56 개의 검체를 대상 으로 하였다. $\mathrm{A}$ 형 간염의 임상 진단은 급성 간염의 임상 양상 과 생화학적 검사에서 간기능 검사의 이상을 동반하고 혈청 anti-HAV IgM 항체가 양성인 경우로 하였다. 환자의 의무기 록을 검토하여 연령, 성별, 주거지, 입원 전의 전구 증상과 퇴 원할 때까지의 증상 등과 입원 기간, 검사실 자료, 간 영상학적 검사 등을 조사하였다.

\section{Virus 감염 검사}

바이러스성 감염을 확인하는 방법으로서 anti-HAV IgM 검 사를 하였는데, ELFA 검사법을 이용하는 VIDAS 장비를 이용 하여 수행하였다. Anti-HAV IgM 양성 결과를 보인 혈청을 $-70^{\circ} \mathrm{C}$ 에서 보관하였다가 실험에 사용하였으며, 다른 바이러스 성 감염에 의한 영향을 배제하기 위하여 B형 간염 바이러스 (hepatitis B virus, HBV), C형 간염 바이러스(hepatitis $C$ vi$\mathrm{rus}, \mathrm{HCV})$ 에 대한 검사를 시행하여 음성 결과를 보인 검체만 을 실험에 사용하였다.

\section{핵산 추출 및 $\mathrm{CDNA}$ 합성}

Anti-HAV IgM 양성 결과를 보인 혈청 $200 \mu 1$ 을 Viral Gene-spin ${ }^{\mathrm{TM}}$ Viral DNA/RNA Extraction Kit (iNtRON
Biotechnology Inc., Korea)를 이용하여 바이러스 핵산을 추출 하였다. 추출된 핵산은 $0.8 \%$ agarose gel을 이용하여 확인하였 다. cDNA 합성은 Power cDNA Synthesis Kit (iNtRON Biotechnology Inc., Korea)의 제조 방법에 따라 $42^{\circ} \mathrm{C}$ 에서 1 시 간 동안 반응시켰다.

\section{$\mathrm{PCR}$ 및 염기서열 결정}

$\mathrm{A}$ 형 간염바이러스의 VP1/P2A 영역을 증폭시키기 위하여 합성된 $\mathrm{cDNA}$ 을 주형으로 nested PCR을 실시하였다. 사용된 바깥쪽 primer와 안쪽 primer는 Table 1에 표시하였다. PCR 반응액은 2× PCR Master mix Solution $\left(i-\mathrm{Taq}^{\mathrm{TM}}\right.$; iNtRON Biotechnology Inc., Korea) $10 \mu \mathrm{l}$, cDNA $8 \mu \mathrm{l}$ 와 primer 각각 $1 \mu \mathrm{l}$ 을 넣은 후 증폭하였다. $\mathrm{PCR}$ 증폭 반응조건은 $94^{\circ} \mathrm{C}$ 에서 10 분간 전처리 변성과정을 거친 후, $94^{\circ} \mathrm{C}$ 에서 40 초 동안 변성 시키고, $61^{\circ} \mathrm{C}$ 에서 1 분간 결합시킨 후 $72^{\circ} \mathrm{C}$ 에서 1 분간 신장시 키는 과정을 40 회 반복하였고, 마지막으로 $72^{\circ} \mathrm{C}$ 에서 10 분간 신장시켰다. 첫 번째 증폭이 끝난 후 그 증폭산물 $1 \mu \mathrm{l}$ 을 주형 으로 안쪽 primer와 함께 두 번째 증폭하였다. 증폭 조건은 첫 번째와 동일하였다. 증폭산물은 agarose로 전기영동 한 후 ethidium bormide로 염색하여 $472 \mathrm{bp}$ 크기의 band를 확인 하였다. 염기서열 분석을 위해 증폭 산물은 MEGAquick$\operatorname{spin}^{\mathrm{TM}}$ Total Fragment DNA Purification Kit (iNtRON Biotechnology Inc., Korea)로 정제하였으며, 염기서열 분석은 capillary 방식의 3730x/DNA Analyzer (Applied Biosystems) 를 이용하였다.

\section{계통분류학적 분석(Phylogenetic analysis)}

결정된 $\mathrm{A}$ 형 간염바이러스 VP1/P2A 영역의 염기서열의 유 사도는 BLAST (http://blast.ncbi.nlm.nih.gov/)을 이용하여 GenBank 데이터베이스와 비교·검색 하였다. 또한 GenBank 데이터베이스에서 $\mathrm{HAV}$ 각 유전자형의 염기서열을 찾아 비교 하였는데, 각 유전자형의 표준으로 사용된 바이러스의 strain 명과 accession number 및 각각의 검출된 국가 $[4,6,17,25]$ 는 Table 2에 표시하였다. 계통분류학적 분석은 PHYDIT [2] 프로 그램을 이용하였으며, 염기서열 정렬은 CLUSTAL_X 프로그 램(v1.64b) [26]으로 multiple alignment를 수행하였다. 계통수 작성은 neighbor-joining [23] 방법을 이용하였으며 진화거리 는 Jukes와 Cantor [9]의 식을 이용하였다. 계통수의 신뢰도는 1,000 회 반복을 통한 bootstrap 분석[5]을 실시하여 확인하였다.

Table 1. Primers used in the one-step and nested PCR for the detection of hepatitis A virus

\begin{tabular}{llll}
\hline \multirow{2}{*}{ Steps } & Primer's name & \multicolumn{1}{c}{ Sequences $\left(5^{\prime} \rightarrow 3^{\prime}\right)$} & Product size $(\mathrm{bp})$ \\
\hline \multirow{2}{*}{ External } & AVF1 & $5^{\prime}$-GGTTTCCGGTCACTGTGCAAATTA-3 & 507 \\
\cline { 2 - 4 } & AVR1 & $5^{\prime}$-AGTAAGAACTCCGCGATCCATTTC-3' & 507 \\
\hline \multirow{2}{*}{ Internal } & AVF2 & $5^{\prime}$-TTGCAAATTACATCGATTCTG-3' & 472 \\
\cline { 2 - 4 } & AVR2 & $5^{\prime}$-TTCAAGAGTCCATTCACTTCT-3' & 472 \\
\hline
\end{tabular}


Table 2. Level of polyprotein VP1/P2A junction nucleotide sequences similarity of hepatitis A virus

\begin{tabular}{|c|c|c|c|c|c|c|c|}
\hline Sample No. & Genotype & Nearest neighbour (NCBI BLAST) & Similarity & $\begin{array}{c}\text { Accession } \\
\text { No. }\end{array}$ & Sources & $\begin{array}{c}\text { Geographical } \\
\text { location }\end{array}$ & $\begin{array}{l}\text { Date of } \\
\text { isolation }\end{array}$ \\
\hline AV-1,2,3,50-AVF & IIIA & Hepatitis A virus HAVSEOUL450 & 100.00 & GU991331 & serum & Korea & 2008.09 .01 \\
\hline AV-4,45,47-AVF & IIIA & Hepatitis A virus HS-14/12/00 & 100.00 & AF386889 & serum & Spain & 2000.12 .14 \\
\hline AV-5,33-AVF & IIIA & Hepatitis A virus HS-14/12/00 & 99.48 & AF386889 & serum & & 2000.12 .14 \\
\hline $\begin{array}{l}\text { AV-6,8,9,13,14,15,19, } \\
20,21,22,23,24,25,27, \\
28,29,32,36-A V F\end{array}$ & IIIA & Hepatitis A virus HS-14/12/00 & 98.97 & AF386889 & serum & Spain & 2000.12 .14 \\
\hline AV-7-AVF & IIIA & Hepatitis A virus HAVSEOUL450 & 98.95 & GU991331 & serum & Korea & 2008.09.01 \\
\hline AV-10-AVF & IIIA & Hepatitis A virus CP-IND & 97.94 & DQ991029 & feces & India & 1992-2004 \\
\hline AV-11-AVF & IIIA & Hepatitis A virus HS-14/12/00 & 99.74 & AF386889 & & & 2000.12 .14 \\
\hline AV-12-AVF & IIIA & Hepatitis A virus HS-14/12/00 & 99.23 & AF386889 & serum & Spain & 2000.12 .14 \\
\hline AV-16-AVF & IIIA & Hepatitis A virus HS-14/12/00 & 99.23 & AF386889 & serum & Spain & 2000.12 .14 \\
\hline AV-17,46-AVF & IIIA & Hepatitis A virus HAVSEOUL247 & & GU991306 & & & 2008.06 .04 \\
\hline AV-18-AVF & IIIA & Hepatitis Av irus CP-IND & 97.42 & DQ991029 & feces & India & 1992-2004 \\
\hline AV-26,43-AVF & IIIA & Hepatitis A virus HS-14/12/00 & 99.48 & AF386889 & serum & Spain & 2000.12 .14 \\
\hline AV-30-AVF & IIIA & Hepatitis A virus HS-14/12/00 & 98.45 & AF386889 & serum & & 2000.12 .14 \\
\hline $\mathrm{AV}-31-\mathrm{AVF}$ & IIIA & Hepatitis A virus HS-14/12/00 & & AF386889 & & & 2000.12 .14 \\
\hline AV-34-AVF & IA & Hepatitis A virus HAJ04-3 & 100.00 & AB258604 & serum & Japan & 2009.01 .10 \\
\hline AV-35-AVF & IIIA & Hepatitis A virus HS-14/12/00 & 98.45 & AF386889 & serum & Spain & 2000.12 .14 \\
\hline $\mathrm{AV}-37-\mathrm{AVF}$ & IIIA & Hepatitis A virus HAVSEOUL247 & 99.74 & GU991306 & serum & Korea & 2008.09.01 \\
\hline $\mathrm{AV}-38-\mathrm{AVF}$ & IIIA & Hepatitis A virus HS-14/12/00 & 99.48 & AF386889 & serum & Spain & 2000.12 .14 \\
\hline AV-39-AVF & IIIA & Hepatitis A virus Moscow-1999-102 & 99.74 & AY226600 & NA & Russia & 2005.02.11 \\
\hline AV-40-AVF & IIIA & Hepatitis A virus HS-14/12/00 & 99.23 & AF386889 & & Spain & 2000.12 .14 \\
\hline AV-41,42-AVF & IA & Hepatitis A virus HAVSEOUL18 & 99.21 & GU991274 & serum & Korea & 2007.04 .04 \\
\hline AV-44-AVF & IA & Hepatitis A virus HAJ04-3 & 99.74 & AB258604 & serum & Japan & 2009.01 .10 \\
\hline $\mathrm{AV}-48-\mathrm{AVF}$ & IIIA & Hepatitis A virus 1006-17909-Toyam P-457 & 99.23 & AB643811 & stool & Japan & 2010.06 \\
\hline AV-49-AVF & IIIA & Hepatitis A virus HS-14/12/00 & 99.48 & AF386889 & serum & Spain & 2000.12 .14 \\
\hline
\end{tabular}

*Sequence similarity was compared using NCBI BLAST

\section{결 과}

\section{검사 대상자들의 특징}

총 56 명의 검사 대상자들 중 남자는 27 명 $(48.2 \%)$, 여자는

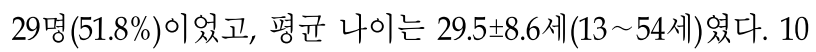
대 6명 $(10.7 \%)$, 20대 27명 $(48.2 \%), 30$ 대 16명 $(28.6 \%)$, 40대 6명 $(10.7 \%), 50$ 대 이상은 1 명 $1.8 \%)$, 그리고 10 세 이하는 한명도 없었다. 환자들의 평균 입원 기간은 $8.1 \pm 2.8$ 일이었으며, 합병 증 없이 모두 회복하여 사회로 복귀하였다. 내원 당시 다른 동반 질환으로는 지방간 3 명 $(5.4 \%)$, 고혈압 1 명 $(1.8 \%)$, 고지혈 증 1 명 $(1.8 \%)$, 당뇨 2 명 $(3.6 \%)$ 이었다. 만성 B형 간염 이나 만성 C형 간염 환자는 없었다. 지역별로는 광주광역시 20 명, 부산광 역시 13 명으로 대부분을 차지하였으며 경남 창원시 7 명, 서울 특별시 4 명, 충남 아산시 4 명, 대구광역시 2 명 그리고 충북 청주시, 경북 포항시, 경기도 성남시, 강원도 강릉시, 강원도 원주시, 전북 전주시에 각각 1 명씩이었다.

\section{VP1/P2A 영역 증폭}

1 차 PCR에서 $507 \mathrm{bp}$ 에서 밴드를 보인 검체를 양성으로 판
정하였고, 2차 PCR에서는 $472 \mathrm{bp}$ 에서 밴드를 보인 검체를 양 성으로 판정하였다. 56 개의 혈청 중 50 개 $(89.3 \%)$ 에서 양성 밴 드를 확인할 수 있었으며, 그 중에서 일부만 표시하였다(Fig. 1). 2차 PCR에 사용된 primer를 이용하여 HAV VP1/P2A 영 역의 $394 \mathrm{bp}$ 에 대해 염기서열을 정렬하고 기존에 보고된 유전 자형과의 유사성을 분석하였다. 4 개 $(8.0 \%)$ 혈청에서는 IA 유 전자형이고, 나머지 46 개 $(92.0 \%)$ 혈청에서는 IIIA 유전자형이 었다(Fig. 2).

$\mathrm{IA}$ 유전자형의 혈청들 중 2개(AV-41-AVF, AV-42-AVF)는 서 로 $100 \%$ 일치하였으며, 한국에서 분리 보고된 HAVSEOUL18주 (GU991274)와는 99.21\%의 유사도를 보였다. 또한 1개(AV-

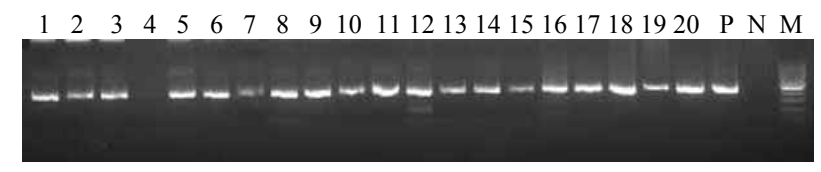

Fig. 1. Example of nested-PCR products from sera positive for Anti-HAV IgM. Lane 1-20, specimens; P, positive control; $\mathrm{N}$, negative control; $\mathrm{M}$, size marker 
34-AVF)는 일본에서 분리 보고된 HAJ04-3주(AB258604)와 $100 \%$ 의 유사도를 보였으며, 나머지 1개(AV-44-AVF)는 $99.74 \%$ 의 유사도를 보였다. IIIA 유전자형을 갖는 혈청들 중 34 개는 최근연 스페인에서 처음 보고된 virus HS-14/12/00주 (AF386889) 이였으며 유사도는 $98.45-100 \%$ 사이에 들었다. 특 히 3개의 혈청에서(AV-4-AVF, AV-45-AVF, AV-47-AVF)는 서로 $100 \%$ 의 유사도를 보였으며, HS-14/12/00주(AF386889) 와 $100 \%$ 의 유사도를 보였다. 또한 동일한 염기서열을 가진 18 개의 혈청(AV-6-AVF, AV-8-AVF, AV-9-AVF, AV-13-AVF, AV-14-AVF, AV-15-AVF, AV-19-AVF, AV-20-AVF, AV-21-
AVF, AV-22-AVF, AV-23-AVF, AV-24-AVF, AV-25-AVF, AV-27-AVF, AV-28-AVF, AV-29-AVF, AV-32-AVF, AV-36AVF AV-1-AVF, AV-2-AVF, AV-3-AVF, AV-50-AVF)도 HS-14/12/00주(AF386889)와 98.97\%의 유사도를 보였다.

한국에서 보고된 염기서열과 연관되어, 가장 유사한 염기서 열을 갖고 있는 혈청은 9개 이었다. HAVSEOUL450주 (GU991331)의 가장 유사한 염기서열로 확인된 혈청은 모두 5 개로, 이 중 4 개는 $100 \%$ 의 유사도를 보였다. 또한 2 개의 혈청 은 가장 유사한 주로 한국에서 분리 보고된 HAVSEOUL247주 (GU991306)와 99.7\% 이상의 유사도를 나타냈다. 2개의 혈청

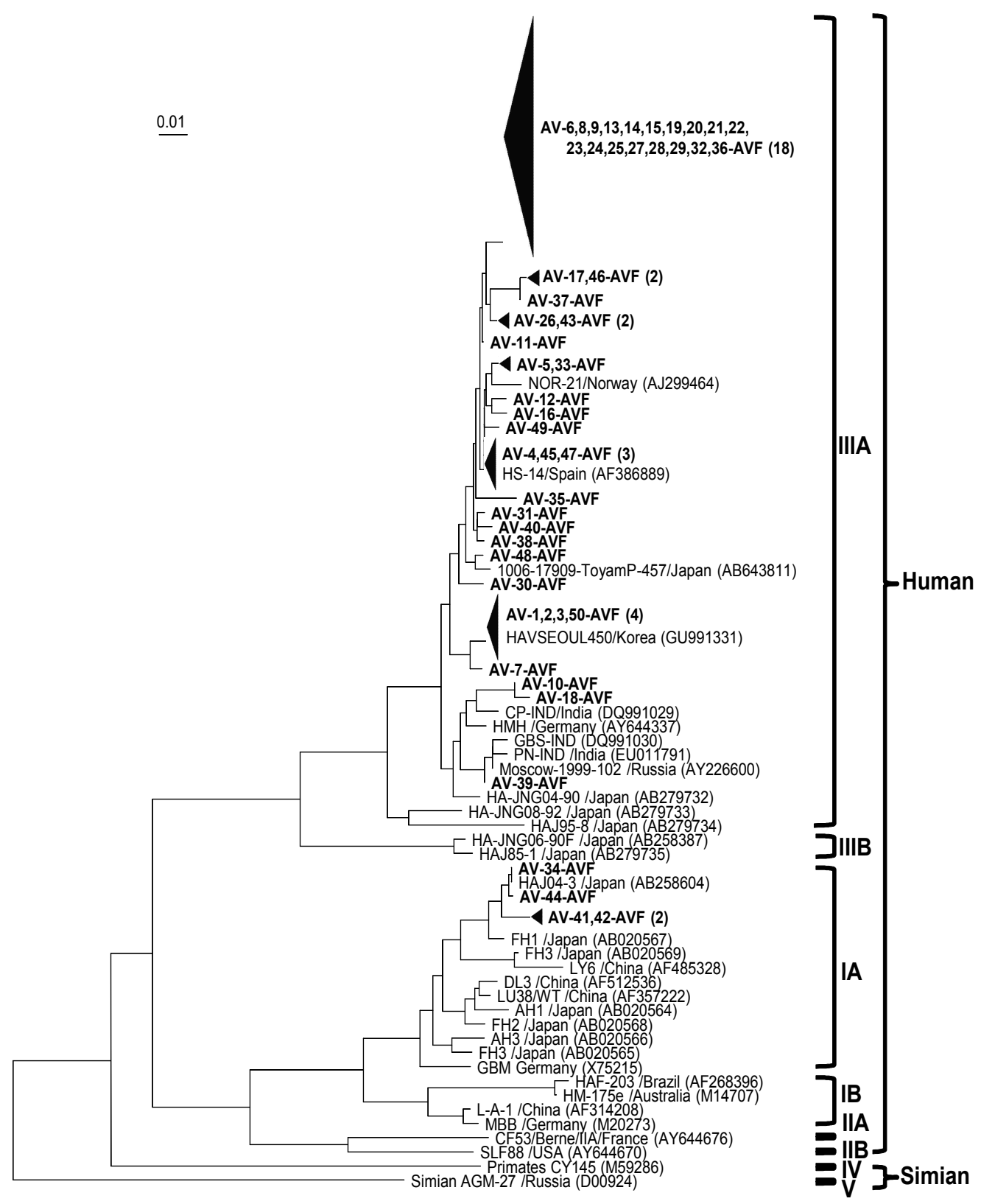

Fig. 2. Neighbor-joining phylogenetic tree of the VP1/P2A junction showing the relationship between wild-type HAV isolates of this study and other hepatitis A virus strains. Bar, 0.01 substitutions per nucleotide. 
도 한국에서 분리 보고된 HAVSEOUL18주(GU991274)의 가 장 유사한 염기서열과의 비교에서 $99.2 \%$ 의 유사도를 나타냈 다. 이외에 인도(2개), 러시아(1개), 일본(2개)에서 보고된 염기 서열과 가장 유사한 염기서열을 갖는 시료는 5 개 이었다(Fig. 2, Table 2).

\section{고 찰}

$\mathrm{A}$ 형 간염의 진단은 임상소견을 참고하여 $\mathrm{A}$ 형 간염 바이러 스에 의해 생성된 anti-HAV $(\mathrm{IgM})$ 를 혈청에서 확인하는 것이 다[8]. 환자가 입원한 직후에 $\mathrm{IgM}$ 항체가 음성으로 나오기도 하는데 이때에도 $\mathrm{A}$ 형 간염이 의심되는 경우에는 3 일 후 재검 하면 대부분에서 혈청 전환을 확인 할 수 있다[16]. 국내 $\mathrm{A}$ 형 간염과 관련된 다양한 임상증상들이 보고되어 있는데 대부분 을 차지하는 것은 흑색 소변(dark urine), 구토, 열, 심신미약, 식용부진 등 이었다[13]. 특히, 급성신부전의 경우, 급성 $\mathrm{A}$ 형 간염환자와 관련성이 없는 것으로 알려져 있었으나 조사에 의하면 간염이 있는 환자는 신부전의 가능성이 있는 것으로 보고되었다[12]. 2009년 2월부터 같은 해 7월까지 조사한 바에 의하면 비급성 $\mathrm{A}$ 형 간염환자 65 명 중 5 명이 급성 신기능 손상 을 동반하였고, 이런 환자의 경우 IIIA 유전자형을 가지고 있 었으며, 이 환자들의 VP1절편의 염기 서열은 급성 신기능 손 상이 없었던 환자들과 동일하다고 보고하였다[30]. 따라서 급 성 신기능 손상이 있는 $\mathrm{A}$ 형 간염환자나 또는 그렇지 않은 합 병증이 없는 A형 유전자형을 가진 환자들에서는 VP1 염기서 열 차이가 없다는 사실을 알 수 있다. 이런 면에서 보면 향후 $\mathrm{HAV}$ 유전체의 VP1 부위 이외의 다른 부위에 대한 염기서열 의 분석을 포함한 연구가 필요할 것으로 생각된다.

$\mathrm{A}$ 형 간염 바이러스는 총 7 종의 유전자형이 있으며 이 중 사람에게 발견되는 유전자형은 I, II, III, VII 네 가지이다[18, $20,21]$. 한국은 지역적으로 동아시아에 위치하고 $\mathrm{A}$ 형 간염 중간정도의 유행지역으로 I 유전자형이 유행하는 것으로 알려 져 있다. 전 세계적으로 널리 퍼진 I 유전자형의 아형인 IA 유전자형은 주로 미국, 중남미(코스타리카, 멕시코, 브라질), 구소련, 중국, 일본과 태국 등에서 발견되며, $\mathrm{IIIA}$ 유전자형은 주로 인도, 네팔, 스리랑카, 말레이시아에서 발견되고, 유럽의 경우에는 나라에 따라서 약간 차이가 있다. 즉, IA 유전자형은 주로 스위스, 영국, 독일, 이탈리아에서 발견되고 IIIA 유전자 형은 스웨덴에서 발견되었다[7, 20].

국내 A형 간염의 경우, 1999년 12월부터 2000년 1월 사이에 조사한 보고에 의하면 IA 유전자형이 대부분이었고[11], 2005 년도 보고에 의하면 $\mathrm{A}$ 형이 $49.5 \%$, B형이 $45.2 \%$ 로 약간 $\mathrm{A}$ 형이 높아졌으며[24], 2007년도 보고에서는 IA 유전자형의 비율이 $71.4 \%$ 비율로 증가하였다고 하였다[19]. 그 이후에는 상황이 완전히 역전되는 것으로 조사되었다. 즉, 2009년도에 보고된 바에 의하면 우리나라 11 개 지역에서 채취한 간염에 감염된
49검체 중 47 검체에서 IIIA 유전자형으로 나타나 $95.9 \%$ 의 아 주 높은 비율을 보였다고 하였다[14]. 따라서 국내에서는 간염 의 주요한 원인으로 IA 유전자형에서 이미 전환되어 IIIA 유전 자형이 대부분이라고 하였다[29]. 본 연구에서도 연구 대상 56 개의 검체들 중 RT-PCR에서 음성이었던 6개의 검체를 제외한 바이러스가 분리된 50 개의 검체에 대해서 유전자형을 분석하 였더니 IA 유전자형은 4 명 $(8.0 \%)$ 이었고, IIIA 유전자형은 46 명 (92.0\%)으로 분석되었다. 따라서 근래 발표된 다른 연구 결과 와 마찬가지로 이번 연구를 통해 여전히 유전자형 IA가 분리 되고 있지만, $\mathrm{IIA}$ 유전자형이 $90 \%$ 를 넘게 검출되어 유전자형 변화양상이 바뀌는 상황이라는 것을 확인할 수 있었다. 전국 적으로도 이는 과거의 IA 유전자형에서 현재는 IIIA 유전자형 으로 바뀌었음을 나타낸다고 할 수 있다. 본 연구에서도 IIIA 유전자형이 광주광역시, 부산광역시, 경남 창원시, 서울시, 충 남 아산시, 대구광역시, 그리고 충북 청주시, 경북 포항시, 경 기도 성남시, 강원도 강릉시, 강원도 원주시, 전북 전주시 등 전국적으로 얻은 검체에서 높은 비율로 나타나 기존의 결과를 뒷받침하였다.

성인이 A형 간염에 감염될 경우, 급성 간부전을 비롯하여 신부전, 췌장염, 담낭염 등의 증상이 나타나 일상생활이나 사회생활에 지장을 초래하게 된다. 따라서 이를 예방하기 위 해서는 $\mathrm{A}$ 형 간염 백신을 접종하는 것이 중요하다. 백신 안전 성의 경우에 이미 27개국에서 수행된 조사에 따르면 $\mathrm{A}$ 형 간염 백신은 안전하며, 모든 연령세대에 걸쳐 높은 면역력을 보인 다고 하였다[3]. 또 A형 간염에 노출된 2주 후에도 백신을 투여 하면 효과가 있는 것으로 알려져 있다[27]. 만약 감염되었을 경우에는 면역 글로불린을 투여해 증상을 완화시키거나 유병 기간을 단축시킬 수 있는 것으로 알려져 있다[10]. 결론적으로 2010년부터 2011년 사이에 조사한 본 연구에서는 50개 검체 혈청(1, 2차 PCR에서 양성 밴드로 나타난 검체의 수) 중 46개 검체에서 IIIA 유전자형이 나타났다. 즉, $92.0 \%$ 의 높은 비율로 IIIA 유전자형이 검출되었는데, 이는 과거에 높은 비율로 나타 났던 HAV 유전체의 IA 유전자형에서 IIIA 유전자형으로 역 전되었음을 보여준다.

\section{References}

1. Brundage, S. C. and Fitzpatrick, A. N. 2006. Hepatitis A. Am Fam Physician 73, 2162-2168.

2. Chun, J. 1995. Computer-assisted classification and identification of actinomycetes. Ph. D. Thesis, University of Newcastle, Newcastle, United Kingdom.

3. Clemens, R., Safary, A., Hepburn, A., Roche, C., Stanbury, W. J. and André, F. E. 1995. Clinical experience with an inactivated hepatitis A vaccine. I Infect Dis 171(Suppl 1), S44-S49.

4. Endo, K., Inoue, J., Takahashi, M., Mitsui, T., Masuko, K. and Akahane, Y. 2007. Analysis of the full-length genome 
of a subgenotype IIIB hepatitis A virus isolate: primers for broadly reactive PCR and genotypic analysis. J Med Virol 79, 8-17.

5. Felsenstein, J. 1985. Confidence limits on phylogenies: an approach using the bootstrap. Evolution 39, 783-791.

6. Fujiwara, K., Yokosuka, O., Fukai, K., Imazeki, F., Saisho, H. and Omata, M. 2001. Analysis of full-length hepatitis A virus genome in sera from patients with fulminant and self-limited acute type A hepatitis. J Hepatol 35, 112-119.

7. Jansen, R. W., Siegl, G. and Lemon, S. M. 1990. Molecular epidemiology of human hepatitis A virus defined by an antigen-capture/polymerase chain reaction method. Proc Natl Acad Sci USA 87, 2867-2871.

8. Jeong, S. H. 2008. Current status and vaccine indication for hepatitis A virus infection in Korea. Korean J Gastroenterol 51, 331-337.

9. Jukes, T. H. and Cantor, C. R. 1969. Evolution of protein molecules. In mammalian protein metabolism. pp. 21-132, Academic Press, New York.

10. Jung, Y. K. and Kim, J. H. 2009. Epidemiology and clinical features of acute hepatitis A: from the domestic perspective. Korean J Hepatol 15, 438-445.

11. Kim, J. S. and Kim, S. H. 2001. Molecular epidemiology of an outbreak of hepatitis A in Korea. Korean J Clin Pathol 21, 114-118.

12. Kim, S. H., Yoon, H. E., Kim, Y. K., Kim, J. Y., Choi, B. S. Choi, Y. J., Kim, Y. O., Kim, Y. S., Bang, B. K. and Yang, C. W. 2008. Acute hepatitis A associated acute renal failure in adults. Nephron Clin Pract 109, 127-132.

13. Lee, D., Cho, Y. A., Park, Y., Hwang, J. H., Kim, J. W. Kim, N. Y., Lee, D. H., Lee, W. and Jeong, S. H. 2008. Hepatitis $\mathrm{A}$ in Korea epidemiological shift and call for vaccine strategy. Intervirology 51, 70-74.

14. Lee, K. O., Jeong, S. J., Seong, H. S., Kim, K. T., Hwang, Y. S. Kim, G. Y. and Lee, S. W. 2009. Genetic analysis of hepatitis A virus isolated from Korea. J Bacteriol Virol 39, 165-171.

15. Lee, K. Y., Song, K. H. and Kang, J. H. 1998. Seroepidemiology of hepatitis A in Taejon, Korea 1996. J Korean Pediatr Soc 41, 53-61.

16. Lee, Y. W., Yang, H. W., Lee, J. A., Yun, K. H., Yang, S. E., Lee, M. J., Park, S. Y., Kim, S. H., Lee, H. I., Lee, Y. J., Jung, S. H., Kim, A. N., Cha, S. W. and Kim, S. Y. 2011. Clinical differences according to genotype in acute viral hepatitis A in Daejeon, Korea. Korean J Med 80, 553-561.

17. Lemon, S. M. 1997. Type A viral hepatitis: epidemiology, diagnosis, and prevention. Clin Chem 43, 1494-1499.

18. Nainan, O. V., Xia, G., Vaughan, G. and Margolis, H. S. 2006. Diagnosis of hepatitis a virus infection: a molecular approach. Clin Microbiol Rev 19, 63-79.
19. Park, J. Y., Lee, J. B., Jeong, S. Y., Lee, S. H., Lee, M. A. and Choi, H. J. 2007. Molecular characterization of an acute hepatitis A outbreak among healthcare workers at a Korean hospital. J Hosp Infect 67, 175-181.

20. Robertson, B. H., Jansen, R. W., Khanna, B., Totsuka, A., Nainan, O. V., Siegl, G., Widell, A., Margolis, H. S., Isomura, S., Ito, K., Ishizu, T., Moritsugu, Y. and Lemon, S. M. 1992. Genetic relatedness of hepatitis A virus strains recovered from different geographical regions. J Gen Virol 73, 1365-1377.

21. Roh, H. O., Sohn, Y. M., Park, M. S., Choi, B. and Bang, K. N. 1997. A seroepidemiologic study of hepatitis A virus in the healthy children and adolescent in Kyonggi-do province. Korean J Pediatr Infect Dis 4, 232-239.

22. Rueckert, R. R. and Wimmer, E. 1984. Systemic nomenclature of picornavirus proteins. J Virol 50, 957-959.

23. Saitou, N. and Nei, M. 1987. The neighbor-joining method: a new method for reconstructing phylogenetic trees. $\mathrm{Mol}$ Biol Evol 4, 406-425.

24. Song, M. H., Lim, Y. S., Song, T. J., Choi, J. M., Kim, J. I., Jun, J. B., Kim, M. Y., Pyun, D. K., Lee, H. C., Jung, Y. H., Lee, Y. S. and Suh, D. J. 2005. The etiology of acute viral hepatitis for the last 3 years. Korean J Med 68, 256-260.

25. Stene-Johansen, K., Jonassen, T. O. and Skaug, K. 2005. Characterization and genetic variability of Hepatitis A virus genotype IIIA. J Gen Virol 86, 2739-2745.

26. Thompson, J. D., Gibson, T. J., Plewniak, F., Jeanmougin, F. and Higgins, D. G. 1997. The CLUSTAL_X windows interface: flexible strategies for multiple sequence alignment aided by quality analysis tools. Nucleic Acids Res 25, 48764882.

27. Victor, J. C., Monto, A. S., Surdina, T. Y., Suleimenova, S. Z., Vaughan, G., Nainan, O. V., Favorov, M. O., Margolis, H. S. and Bell, B. P. 2007. Hepatitis A vaccine versus immune globulin for postexposure prophylaxis. $N$ Engl J Med 357, 1685-1694

28. Weitz, M. and Siegl, G. 1985. Variation among hepatitis A virus strains. I. Genomic variation detected by $\mathrm{T} 1$ oligonucleotide mapping. Virus Res 4, 53-67.

29. Yoon, Y. K., Chun, B. C., Lee, H. K., Seo, Y. S., Shin, J. H. and Hong, Y. S. 2009. Epidemiological and genetic analysis of a sustained community-wide outbreak of hepatitis A in the Republic of Korea, 2008: A hospital-based case-control study. J Clin Virol 46, 184-188.

30. Yoon, Y. K., Sim, H. S., Kim, J. Y., Park, D. W., Sohn, J. W., Chun, B. C. and Kim, M. J. 2010. Clinical characterization of hepatitis A infection complicated with acute kidney injury and sequence analysis of the VP1 region. Korean J Clin Microbiol 13, 7-13. 
초록 : 국내 급성 A형 간염 바이러스의 유전자형 특징

김미현 ${ }^{1} \cdot$ 최하야나 ${ }^{2} \cdot$ 백근식 ${ }^{2} \cdot$ 성치남 $^{2} \cdot$ 조현욱 ${ }^{2}$

(광주 한국병원 임상병리실, ${ }^{2}$ 순천대학교 생명산업과학대학 생물학과)

우리나라에서 $\mathrm{A}$ 형 간염바이러스는 $\mathrm{IA}$ 유전자형이 주된 양상이었으나 최근 일부 다른 유전자형이 점차 늘어나 는 보고들이 발표되고 있다. 따라서 본 연구의 목적은 최근 우리나라에서 유행한 $\mathrm{A}$ 형 간염의 바이러스 유전자형 을 분석하고자 하였다. 2010년 4월에서 2011년 4월까지 광주광역시에 위치한 K 병원에 입원한 급성 $\mathrm{A}$ 형 간염환 자 20명의 검체와 서울에 위치한 S 검사센터에 의뢰된 Anti-HAV IgM 양성인 36개의 검체를 대상으로 하여 검사 를 실시하였다. 또한 Anti-HAV IgM 양성인 56개의 검체인 serum에서 RNA를 분리한 후 VP1/P2A junction 부 위에 대해서 RT-PCR을 통하여 증폭 한 후 염기서열을 분석하여 기존의 발표된 유전자형과 비교하였다. 유전자형 분석결과 바이러스가 분리된 50 명에서 4 명 $(8 \%)$ 은 IA 유전자형을, 46 명 $(92 \%)$ 은 IIIA 유전자형을 보였다. 이번 연 구를 통하여 우리나라에서 발생한 $\mathrm{A}$ 형 간염환자의 유전자형 분석에서 과거와는 달리 IA 유전자형이 아닌 IIIA 유전자형으로 변하였다는 것을 확인 할 수 있었다. 